\title{
The Clinical Relevance of Elevated Blood Lead Levels in Opium Addicts with Severe Abdominal Pain
}

\author{
Iraj Shahramian ${ }^{1}$, Noor Mohammad Noori ${ }^{2}$, Mahdi Afshari ${ }^{3}$, \\ Mojtaba Delaramnasab ${ }^{4}$, Ali Bazi ${ }^{4}$, Motahareh Abdollahi ${ }^{5}$ \\ ${ }^{1}$ Department of Pediatrics, Zabol University of Medical Sciences, Zabol, Iran, ${ }^{2}$ Depart- \\ ment of Pediatric Cardiology, Children and Adolescents Health Research Center, Zahedan \\ University of Medical Sciences, Zahedan, Iran, ${ }^{3}$ Department of Community Medicine, \\ Zabol University of Medical Sciences, Zabol, Iran, ${ }^{4}$ Clinical Research Development Unit, \\ Amir-Al-Momenin Hospital, Zabol University of Medical Sciences, Zabol, Iran, ${ }^{5}$ Committee \\ of Student Research, Zabol University of Medical Sciences, Zabol, Iran
}

\begin{abstract}
There are inconsistencies regarding the association of blood lead level (BLL) in opium addicts with severe abdominal pain. In present study, we aimed to assess BLL in opium addicts presented with severe abdominal pain. This cross-sectional study was conducted on 60 opium-addicted individuals admitted to our rehabilitation center in Zabol city during February-October 2016. BLL was measured using potentiometricstripping analysis (PSA) method. Statistical analysis was conducted in SPSS 20 software. From 60 addicts recruited, 47 (78.3\%) were males. The mean age was $40.3 \pm 18.1$ years old. The mean BLL was $43.1 \pm 117.4 \mu \mathrm{g} /$ dl. Considering a threshold of $18 \mu \mathrm{g} / \mathrm{dl}, 22$ (37.6\%) of the addicts had elevated BLL. The mean BLL in addicts with oral, inhalation and mixed method of consumptions were $54.9 \pm 1.5 \mu \mathrm{g} / \mathrm{dl}, 47.4 \pm 9.2 \mu \mathrm{g} / \mathrm{dl}$, and $10.1 \pm 95$ $\mu \mathrm{g} / \mathrm{dl}$ respectively $(\mathrm{P}=0.5)$. No differences were found regarding the mean $\mathrm{BLL}$ among different age groups or between different genders. Furthermore, there were no significant difference in neither hematological parameters or liver enzyme in addicts with normal and elevated BLL. The BLL was not of significant difference in addicts with different methods of opium usage and severe abdominal pain. It is recommended to investigate the effects of factors such as the duration of opium usage and the concentration of lead in opium to influence BLL.
\end{abstract}

Keywords: lead toxicity, opiate narcotics, addiction, abdominal pain, opium

Copyright (C) 2019 KBCSM, Zagreb

e-mail: alcoholism.kbcsm@gmail.com•www.http://apr.kbcsm.hr

Correspondence to: Amir-Al-Momenin Hospital, Zabol University of Medical Sciences, Zabol, Iran

Tel/Fax: +98 32239031, E-mail: m.baziali@gmail.com

\section{Introduction}

Lead toxicity is a traditional health concerning issue concerning mankind from ancient times. During industrial development in $19^{\text {th }}$ and early $20^{\text {th }}$ centuries, lead toxicity became highly commonplace in industrial em- 
ployees [1]. However, patterns of lead toxicity have transformed in recent years $[1,2]$. Occupational exposure in miners, contamination through food digestion or air inhalation are common potential sources of lead toxicity. Furthermore, concerns have been expressed toward the lead toxicity in addicts consuming adulterated narcotics [3-5]. Accordingly, opium addicts have been reported to have higher blood lead level (BLL) compared to healthy counterparts. Although this may be due to the usage of adulterated opium, the exact source of lead-contaminated opium is unclear [6]. Opium is of high economical value in most countries and in Iran, and this may encourage dealers to add this heavy metal to opiates in order to increase its weight and value.

Lead is responsible for many toxic effects toward human body. The elevated BLL can inflict adverse neurological, renal, cardiovascular, and hepatic effects [7-9]. Lead poisoning also causes a wide range of non-specific gastrointestinal symptoms including abdominal pain, nausea, and constipation [10]. In fact, gastrointestinal manifestations comprise the most common reported symptoms in lead-poisoned opium addicts [5].

Opium is the most popular narcotic among Iranian addicts [11]. Opium addiction is especially high in the south-east of Iran which is in neighborhood of countries exporting embargoes of opium. Regarding the carcinogenic potential of lead, screening lead toxicity in high-risk individuals such as opium addicts is important. The majority of previous reports on opium related lead toxicity have mainly assessed only one method of opium usage (namely inhalation or digestion). There are few studies comparing the effects of the methods of opium usage on
BLL. In present study, we measured BLL in opium addicts with a history of abdominal pain, and assessed a potential relationship between BLL and the method of opium consumption.

\section{Participants and methods}

The current analytical cross-sectional study was performed in the Addict Rehabilitation Center of Zabol city, the south east of Iran during February-October 2016. The age spectrum of the recruited opium addicts ranged from 3 to 76-year-old. The participants were chosen based on convenient sampling method. Those addicts presented with severe abdominal pain were recruited. The methods of usage were oral ingestion, inhalation or both. Inclusion criteria included being addicted for at least 6 months. Individuals at risk of occupational lead poisoning were excluded (miners, painters, and those working with wires and cables).

Our research was approved by the Ethical Committee of Research of Zabol University of Medical Sciences. Also, recruited patients were asked to fill an informed consent. Demographic information was gathered by interviews.

\section{Blood lead level (BLL) assay}

Blood samples $(3 \mathrm{ml})$ were collected in tubes containing serum separator. The samples were labeled with patients' names as well as with specific ID numbers assigned for future data retrieving. The samples were immediately transferred to the laboratory, and serum samples were separated by centrifugation and stored at -20 until use.

BLL was measured by potentiometricstripping analysis (PSA) method using Heavy 
Metal Analyzer ION ${ }^{3}$ (Steroglass, S. Martino in Campo, Perugia, Italy). This is a highsensitivity method for measuring multiple heavy metals in multiple types of samples. Three electrodes are used in this method including carbon graphite electrode (working electrode), $\mathrm{Ag} / \mathrm{AgCl}$ (reference electrode) and platinum (as counter electrode). At first, working carbon electrode was covered with mercury by electrolyzing of $20 \mathrm{ml} \mathrm{Hg}^{2+}(1000$ $\mathrm{mg} / \mathrm{kg}$ ). Then, BLL was measured through electrolyzing and striping steps. At the first step, the ion was reduced and placed on the working electrode, and at the second step, the ion was stripped from the surface of the electrode. The level of lead in the samples was determined by reading the peak of the stripping curves $[12,13]$.

\section{Statistical analysis}

Frequencies and mean and standard deviations were applied for reporting qualitative and quantitative variables respectively. The data distribution was assessed by Shapiro-Wilk test. The association of BLL with the method of opium consumption was checked using Chi-square and Fischer exact tests. The mean differences of BLL among different opiumusage methods were sought using One-way ANOVA. All the analyses were performed in
SPSS version 20 software. A P value $<0.05$ was considered as statistically significant.

\section{Results}

Overall, 60 addicts with severe abdominal pain were investigated. Of these, 47(78.3\%) were males. The mean age of the patients was $40.33 \pm 18.10$ years old. The youngest and the oldest patients had 3 and 76 years old respectively. The frequencies of oral ingestion, inhalation and combined opium usage methods were 17 (28.3\%), $30(50 \%)$ and 13 $(21.7 \%)$ respectively.

The mean BLL was $43.11 \pm 117.43 \mu \mathrm{g} / \mathrm{dl}$ in the addicts. Considering the $18 \mu \mathrm{g} / \mathrm{dl}$ cut off, $22(37.6 \%)$ of the addicts had abnormal BLL. Minimum and maximum BLL levels were $0.55 \mu \mathrm{g} / \mathrm{dl}$ and $825 \mu \mathrm{g} / \mathrm{dl}$ respectively (Table 1).

As illustrated in table 2, the frequencies of abnormal BLL in oral ingestion, inhalation and combined opium usage methods were 7 (41.2\%), $12(40 \%)$ and $3(23.1 \%)$ respectively (0.53). There was no statistically significant association between BLL and the method of opium consumption. In addition, the assessment of hematological parameters and liver enzymes revealed no significant differences between addicts with normal and abnormal BLL (Table 3).

Table 1. Blood lead level categories in 60 opium addicts presented with abdominal pain.

\begin{tabular}{crc}
\hline Blood lead level $(\mu \mathrm{g} / \mathrm{dl})$ & $\mathrm{N}$ & Percent \\
\hline$<18$ & 38 & 63.3 \\
$18-35$ & 11 & 18.3 \\
$36-45$ & 2 & 3.3 \\
$>45$ & 9 & 15 \\
\hline
\end{tabular}


Table 2. Blood lead levels in opium addicts based on gender and the methods of consumption

\begin{tabular}{|c|c|c|c|c|c|c|}
\hline \multicolumn{2}{|c|}{ Factors } & \multicolumn{2}{|c|}{$\begin{array}{c}\text { BLL } \\
(\mathrm{N}=60)\end{array}$} & \multirow[t]{2}{*}{$\mathrm{P} *$} & \multirow[t]{2}{*}{$\begin{array}{c}\text { BLL } \\
\text { Mean } \pm \text { SD }\end{array}$} & \multirow[t]{2}{*}{$\mathrm{P}$} \\
\hline & & $\begin{array}{c}\text { Normal } \\
\mathrm{N}=38 \\
\mathrm{n}(\%)\end{array}$ & $\begin{array}{c}\text { Abnormal } \\
\mathrm{N}=22 \\
\mathrm{n}(\%)\end{array}$ & & & \\
\hline \multirow{3}{*}{$\begin{array}{l}\text { Methods of } \\
\text { Opium usage }\end{array}$} & Oral & $10(58.8)$ & $7(41.2)$ & 0.5 & $47.4 \pm 9.2$ & $0.5^{* * *}$ \\
\hline & Inhalation & $18(60)$ & $12(40)$ & & $54.9 \pm 1.5$ & \\
\hline & Mixed & $10(76.9)$ & $3(23.1)$ & & $10.1 \pm 9.5$ & \\
\hline \multirow[t]{2}{*}{ Gender } & Male & $27(57.4)$ & $20(42.6)$ & 0.1 & $52.6 \pm 1.3$ & $0.2^{* *}$ \\
\hline & Female & 11(84.6) & $2(15.4)$ & & $8.6 \pm 8$ & \\
\hline \multirow[t]{5}{*}{ Age } & $<14$ & $6(75)$ & $2(25)$ & 0.7 & $9.2 \pm 8.8$ & $0.7^{* * *}$ \\
\hline & $14-25$ & $1(50)$ & $1(50)$ & & $92.5 \pm 123.7$ & \\
\hline & $26-35$ & 7 (63.6) & $4(36.4)$ & & $33.6 \pm 56$ & \\
\hline & $36-59$ & $16(53.3)$ & $14(46.7)$ & & $61.7 \pm 15.8$ & \\
\hline & $>60$ & 8 (88.8) & $1(11.2)$ & & $11.6 \pm 5.5$ & \\
\hline
\end{tabular}

* Fischer exact test, ** Independent sample t-test, *** One-way ANOVA

BLL; Blood lead level

Table 3. Hematological and liver enzymes levels in opium addicts with abdominal pain.

\begin{tabular}{|c|c|c|c|c|c|}
\hline \multirow[t]{2}{*}{ Parameters } & \multicolumn{2}{|c|}{$\begin{array}{l}\text { Normal BLL } \\
\quad(\mathrm{n}=38)\end{array}$} & \multicolumn{2}{|c|}{$\begin{array}{c}\text { Abnormal BLL } \\
(n=22)\end{array}$} & \multirow[t]{2}{*}{$\mathrm{P}$} \\
\hline & Mean & $\mathrm{SD}$ & Mean & $\mathrm{SD}$ & \\
\hline White blood cell count $\left(\times 10^{3} / \mu \mathrm{l}\right)$ & 7920 & 1967.7 & 10540 & 3485.4 & 0.1 \\
\hline Red blood cell count $\left(\times 10^{6} / \mu \mathrm{l}\right)$ & 4.3 & 0.3 & 4.8 & 0.8 & 0.2 \\
\hline Hemoglobin $(\mathrm{g} / \mathrm{dl})$ & 13.6 & 1.5 & 13.1 & 1.1 & 0.8 \\
\hline Hematocrit $(\%)$ & 38.9 & 4 & 38.5 & 1.4 & 0.6 \\
\hline Mean cell volume (fl) & 90 & 5.3 & 81.5 & 12.4 & 0.6 \\
\hline Mean cell hemoglobin (pg) & 31.4 & 2.2 & 27.9 & 5.7 & 0.4 \\
\hline Red cell distribution width & 13 & 1.5 & 14.3 & 1.7 & 0.5 \\
\hline Platelet count $\left(\times 10^{6} / \mu \mathrm{l}\right)$ & 249200 & 40778 & 316320 & 88914 & 0.2 \\
\hline Alanine amino transferase (IU) & 14.6 & 2.9 & 14.6 & 2 & 0.9 \\
\hline Aspartate amino transferase (IU) & 25 & 6.9 & 24 & 6 & 0.3 \\
\hline Alkaline phosphatase (IU) & 268.8 & 117 & 299.6 & 144.9 & 0.3 \\
\hline BLL; Blood lead level & & & & & \\
\hline
\end{tabular}




\section{Discussion and Conclusion}

The adulterated opium is an emerging source for lead poisoning worldwide. Among 60 opium addicts presented with severe abdominal pain, we here observed that 22 (37.6\%) had abnormal high BLL. The mean BLL in this group was $43.11 \pm 117.43 \mu \mathrm{g} /$ dl. The males constituted the majority of our patients which is in accordance with previous reports [5]. We observed no significant differences in mean BLL among different age groups, and genders. In current study, the highest BLL levels were observed in the addicts between 35-59 years old (excluding one addict in 14-25 years old age group which was an outlier). Furthermore, the mean BLL $(11.6 \pm 5.5 \mu \mathrm{g} / \mathrm{dl})$ was lower in addicts $>60$ years old than other age groups. In a study on digester or inhaler opium addicts, the subjects with 40-60 years old had the highest BLL. In another study, elderly opium addicts ( $>60$ years old) had the lowest BLL which was similar to our record [8]. There were also no significant associations between BLL and nor age or the duration of opium consumption in the study of Hayatbakhsh et al [14]. The lack of association between gender and BLL in present and precedent studies may root in the relatively low number of female addicts in studies. This explanation may also be applicable for different age groups. Studies with higher number of young and female addicts may clarify any possible associations between BLL and these factors.

Lead poisoning can present with a wide spectrum of clinical manifestations. The clinical presentation may encompass digestive symptoms including abdominal pain and constipation, hematological problems such as anemia, as well as general malaise, fatigue, and hepatic dysfunction [15-17]. The ingestion of opium can further present with acute severe abdominal pain [18]. Abdominal pain, anorexia, and constipation, along with weight loss have been the most common presentations in opium addicts with respective frequencies of $96 \%, 92 \%, 88 \%$, and $84 \%$ [16]. In this study, we selected our target population from opium addicts who presented with severe abdominal pain as the most common encountered symptom in these individuals. However, we found no correlation between BLL and abdominal pain which is in line with the findings of a previous study [16]. Furthermore, abdominal pain was not associated with opium usage methods. Abdominal pain in opium-related lead toxicity is a common feature, and it is critical to be vigilant to avoid the misinterpretation of this entity with other etiologies such as pancreatitis, and cholecystitis [19]. This is important as there have been reports of unnecessary laparotomies (as high as $12 \%$ ) in opium addicts presented with digestive presentations [5]. Searching for a history of opium addiction may be useful in the differentiation of lead-toxicity abdominal pain form other diseases [20].

In our study, we found no association between the method of opium usage and BLL. Although oral opium consumers had BLL levels compared to the inhalers, this difference was not statistically significant. Accordingly, in the study of Amiri and associates who evaluated BLL in 39 opium inhaler and digester addicts, they found no significant difference in BLL between the two groups [8]. This was also in line with another study performed by Khatibi-Moghadam and associates in opium addicts [3]. In another study, BLL was higher in opium oral users than those who inhaled opium [15]. In parallel, Salehi and associates also described that BLL was correlated with the dose of ingested opium in addicts [21]. In fact, it seems that heat 
applied in inhalation method of opium usage affects the lead concentration [14]. Furthermore, the duration of opium consumption may be a determining factor [5]. Nevertheless, these variables were not determined in present study, and therefore it is recommended to include such factors in future studies.

In conclusion, our study showed that BLL was associated with neither gender, age nor the method of opium consumption among opium addicts presented with severe abdomi-

\section{References}

1. Gidlow D. Lead toxicity. Occup Med. 2015;65:34856.

2. Karrari P, Mehrpour O, Abdollahi M. A systematic review on status of lead pollution and toxicity in Iran; Guidance for preventive measures. Daru. 2012;20:2.

3. Khatibi-Moghadam H, Khadem-Rezaiyan M, Afshari R. Comparison of serum and urine lead levels in opium addicts with healthy control group. Hum Exp Toxicol. 2016;35:861-5.

4. Soltaninejad K, Fluckiger A, Shadnia S. Opium addiction and lead poisoning. Journal of Substance Use. 2011;16:208-12.

5. Meybodi FA, Eslick GD, Sasani S, Abdolhoseyni M, Sazegar S, Ebrahimi F. Oral opium: an unusual cause of lead poisoning. Singapore Med J. 2012;53:395-7.

6. Jalili M, Azizkhani R. Lead toxicity resulting from chronic ingestion of opium. West J Emerg Med. 2009;10:244-246.

7. Beigmohammadi MT, Aghdashi M, Najafi A, Mojtahedzadeh M, Karvandian K. Quadriplegia due to lead-contaminated opium- -case report. Middle East J Anaesthesiol. 2008;19:1411-6.

8. Mojtaba A, Ramin A. A comparison of bloodlead level (BLL) in opium-dependant addicts with healthy control group using the graphite furnace/ atomic absorption spectroscopy (GF-AAS) fol- nal pain. It is recommended to conduct studies with larger populations including higher number of females and young addicts to clarify any association between the demographic features and BLL in opium addicts.

\section{Acknowledgements}

None.

\section{Conflicts of interest}

Authors declare no conflict of interests.

lowed by chemometric analysis. Iranian Red Crescent Med J. 2012:488-91.

9. Mohamed WAM, Abd-Elhakim YM, Farouk SM. Protective effects of ethanolic extract of rosemary against lead-induced hepato-renal damage in rabbits. Exp Toxicol Pathol. 2016;68:451-61.

10. Algora M, Martin-Castillo A, Zabala P, Fernandez $\mathrm{MN}$. Lead poisoning due to drug addiction: a new source of poisoning with clinical interest and important epidemiological consequences. An Med Interna.1989;6:483-5.

11. Malekinejad M, Vazirian M. Transition to injection amongst opioid users in Iran: implications for harm reduction. Int J Drug Policy. 2012;23:333-7.

12. Kaminiwa J, Honda K, Kurosu A, Nishi T, Sugano Y, Yano S. Application of trace element measurement for diagnosis of metabolic disorders. Rom J Leg Med 2013;21:259-62.

13. Saei-Dehkordi SS, Fallah AA. Determination of copper, lead, cadmium and zinc content in commercially valuable fish species from the Persian Gulf using derivative potentiometric stripping analysis. Microchem J. 2011;98:156-62.

14. Hayatbakhsh Abbasi MM, Ansari M, Shahesmaeili A, Qaraie A. Lead serum levels in opium-dependent individuals. Addict Health. 2009;1:106-9.

15. Domeneh BH, Tavakoli N, Jafari N. Blood lead level in opium dependents and its association with anemia: A cross-sectional study from the capital of Iran. J Res Med Sci. 2014;19:939-43. 
16. Shiri R, Ansari M, Ranta M, Falah-Hassani K. Lead poisoning and recurrent abdominal pain. Ind Health. 2007;45:494-6.

17. Verheij J, Voortman J, van Nieuwkerk CM, Jarbandhan SV, Mulder CJ, Bloemena E. Hepatic morphopathologic findings of lead poisoning in a drug addict: a case report. J Gastrointestin Liver Dis. 2009;18:225-7.

18. Masoodi M, Zali MR, Ehsani-Ardakani MJ, Mohammad-Alizadeh AH, Aiassofi K, Aghazadeh R, et al. Abdominal pain due to lead-contaminated opium: a new source of inorganic lead poisoning in Iran. Arch Iran Med. 2006;9:72-5.
19. Dequanter D, Lefebvre J, Takieddine M, Belva P, Vaneukem P. An acute pseudo-cholecystitis. Rev Med Brux. 2001;22:439-41.

20. Macedo G, Lopes S, Peixoto A. Misleading Gastrointestinal Symptoms: The Ongoing Story of Chronic Lead Intoxication. J Clin Gastroenterol. 2016;50:769-71.

21. Salehi H, Sayadi AR, Tashakori M, Yazdandoost $\mathrm{R}$, Soltanpoor N, Sadeghi H, et al. Comparison of serum lead level in oral opium addicts with healthy control group. Arch Iran Med. 2009;12:555-8.

\section{Kliničko značenje povišene razine olova u krvi u ovisnika o opijumu s jakom boli u području abdomena}

Sažetak - Postoje nedosljednosti u vezi povezanosti razine olova u krvi (OUK) u ovisnika o opijumu s jakim bolovima na području abdomena. U ovome radu nam je bio cilj odrediti OUK u ovisnika o opijumu s jakim bolovima u trbuhu. Provedeno je presječno instraživanje na 60 ovisnika o opijumu primljenih u naš rehabilitacijski centar u gradu Zabol od veljače do listopada 2016. OUK je mjereno metodom potenciometrijske striping analize. Statističke analize su učinjene programom SPSS 20. Od ispitanih 60 ovisnika, 47 (78,3 \%) su bili muškarci. Srednja dob je bila $40.3 \pm 18.1$ godina. Srednja vrijednost OUK je bila $43.1 \pm 117.4 \mu \mathrm{g} / \mathrm{DL}$. S obzirom na prag od $18 \mu \mathrm{g} / \mathrm{DL}, 22$ (37,6 \%) ovisnika imalo je povišeno OUK. Srednje vrijednosti OUK u ovisnika koji su sredstvo konzumirali peroralno, inhalacijski i mješano su iznosile 54.9 $\pm 1,5 \mu \mathrm{g} / \mathrm{DL}, 47.4 \pm 9,2 \mu \mathrm{g} / \mathrm{DL}$ i $10.1 \pm 95$ $\mu g / D L(P=0,5)$. Nisu pronađene značajne razlike srednje vrijednosti OUK među različitim dobnim skupinama ili između spolova. Nadalje, nije bilo značajne razlike ni u hematološkim parametrima ili jetrenim enzimima u ovisnika s normalnim i povišenim OUK. OUK se nije značajno razlikovalo u ovisnika s različitim načinima konzumiranja droge i jakim bolovima u trbuhu. Preporuča se istražiti kako čimbenici kao što su trajanje konzumacije opijuma i koncentracija olova u opijum utječu na razinu OUK.

Ključne riječi: toksičnost olova, opijatni narkotici, ovisnost, abdominalna bol, opijum 
